Journal of Engineering and Applied Sciences 15 (2): 567-573, 2020

ISSN: 1816-949X

(C) Medwell Journals, 2020

\title{
Sustainability Status of Raw Water Supply at Ciliman Watershed
}

\author{
${ }^{1}$ Isvan Taufik, ${ }^{2}$ Muhammad Yanuar J. Purwanto, ${ }^{2}$ Bambang Pramudya and ${ }^{2}$ Satyanto K. Saptomo \\ ${ }^{1}$ Department of Environmental and Natural Science, Bogor Agricultural University, \\ Bogor, Indonesia \\ ${ }^{2}$ Institute Pertanian Bogor University, Bogor, Indonesia
}

\begin{abstract}
The supply of sustainable raw water has the aim of developing water resources, so that, water use can be efficient have an economic value, good quality, sustainable and everlasting. The research objective was to determine the sustainability status of raw water supply in the Ciliman watershed. The types of data used are primary data and secondary data. Data sources are collected from the field, library and experts. Data collection methods include library studies and surveys. The developed survey technique were in-depth interviews and questionnaire. The method of data analysis was done using the MDS approach with the modification of Rapfish to RapCiliman. The results of the study shows that the level of sustainability of management in general is categorized as sufficiently sustainable including, ecological dimension 56.53\% (quite sustainable), 62.90\% economic dimension (quite sustainable), 46.76\% social dimension (less sustainable), institutional and legal dimensions 46.13\% (less sustainable) and technological dimensions and infrastructure 66.49\% (quite sustainable). The main lever attributes of sustainability include; ecological dimensions namely, flood frequency (3.77), drought frequency (3.49) and run off coefficient (2.53), economic dimension, namely: availability of raw water supply funds (8.40), water utilization rates (6.66) and investment climate (6.48), social dimensions, namely; public understanding of the sustainability of natural resources (4.82), population pressure (3.78) and community participation in watershed management (2.10), institutional and legal dimensions, namely: organizational capacity of the institution (8.89) and clarity of responsibilities for natural resource management (8.56), dimensions of technology and infrastructure, namely: water building value (9.49), acceptance level for technological innovation (8.61) and type of water supply installation (8.06).
\end{abstract}

Key words: Sustainability, raw water, Ciliman watershed, investment climate, institutional, building value

\section{INTRODUCTION}

The human need for water resources become very evident when associated with four things, namely population growth, food growth, increased industrialization and protection of ecosystems against technology. Various problems related to water resources in Indonesia can be briefly identified, among others, the symptoms of the water crisis, degradation of water resources, conflicts due to competition between water users, reduced irrigated land due to transfer of functions, lack of clarity in the provisions of water tenure rights, weak coordination among agencies within addressing water resources and weaknesses in water resource policies. These problems certainly require the existence of appropriate policy options, so that, the use of water resources can be sustainable. Sustainable development is a development concept that has the principle of "meeting current needs without compromising the fulfillment of the needs of future generations" (World Commission on Environment and Development, 1987). According to
Todaro and Smith (2003), sustainable development is multidimensional in that it covers various aspects of people's lives, not just one aspect (economy). In line with this Munasinghe (1993), states that sustainable development is broadly based on 3 main pillars of development; economic, social and ecological.

Efficient water resources are used precisely and optimally to prevent excessive usage. Procurement and provision of water resources requires a lot of costs. Therefore, its use must be based on economic considerations. The expenditure that must be spent by the user is an investment in water resources management, so that, there is independent financial sustainability. Sustainable water resources can be utilized properly without damaging or reducing the ability of water resources to meet future needs. In addition, the use of water also does not cause irreversible effects.

Thus, the study of the sustainability status of raw water supply in the Ciliman watershed is very important, considering the current and future availability of raw water is the main requirement. The analytical approach

Corresponding Author: Isvan Taufik, Indonesian Centre for Agricultural Land Research and Development, Indonesia Agency for Agricultural Research and Development, Bogor, Indonesia 
used in knowing the overall status of raw water supply in the Ciliman watershed is the Multidimensional Scaling (MDS) approach with Raps-Ciliman tools (Rapid Apparaisal for Ciliman).

\section{MATERIALS AND METHODS}

Data types and sources: The types of data used in the study of the sustainability status of raw water supply in the Ciliman watershed include; primary data and secondary data. Primary data is data obtained directly in the field, especially, those related to raw water management in the Ciliman watershed by conducting surveys and field observations. According to Yusuf and Daris (2018), primary data is generally obtained directly from research objects such as measurement data, observation or interviews with respondents. While secondary data in the study are data obtained from various research-related documents, particularly related to sustainable raw water management. According to Nasution (2011) secondary data is data collected from other people with their own intentions and have categorization or classification according to needs.

Primary data sources are from the field and from respondents. Respondents in this study are general respondents, namely respondents selected from the community who used raw water in the Ciliman watershed. While secondary data comes from agencies or institutions related to the management of raw water in the Ciliman watershed. The form of secondary data are official documents in the form of research results, journals, annual reports or study reports regarding raw water in the Ciliman watershed both in softcopy and hardcopy.

Data collecting method: The data collecting method is a technique or way that is done to collect data with a specific purpose (Sugiyono, 2010). It is closely related to the types of data used, in this case is they are primary data and secondary data. The study include; literature study (desk study) and survey method.

The library study (desk study) is data collected carried out by tracing theory documents and research results in the form of statistical data (information in numbers, reports and other related documents). According to Nazir (1988) that literature study is a technique of collecting data by conducting study studies of books, literature, records and reports that have to do with the things studied/examined. This method is also called the documentation method. According to Arikunto (2006) documentation is looking for and collecting data on matters in the form of notes, transcripts, books, newspapers, magazines, minutes, agendas and so on.
The survey method is a method of primary data collected by interview techniques or filling in a list of questions (questionnaire). According to Singarimbun and Effendi the survey method is a technique of gathering information done by compiling a list of questions posed to respondents. According to Sugiyono (2010) a questionnaire is a technique of data collecting conducted by giving a set of questions or written statements to respondents to be answered. Whereas according to Arikunto (2006) a questionnaire is a written statement used to obtain information from respondents in the sense of reports concerning the person or things that are known. The list of questions or questionnaires developed in the study is an open questionnaire related to raw water management in the Ciliman watershed. In other words, the questionnaire given is only in the form of questions without providing answers, so, the answers will be given freely by the respondent.

Data analysis method: Data analysis method is a technique or method of processing data into information that can provide results for the problems being studied. According to Yusuf and Daris (2018) data analysis is a process of data transformation with a certain analytical method that is standard (valid) to obtain a result in the form of information that can describe the data or become the basis for decision making. According to Sugiyono (2010) data analysis is a method or way to process a data into comprehensive information and beneficial for finding solutions to problems, especially, problems related to research.

The data analysis method developed in this study is the method of MDS (Multidimensional Scaling) approach with the help of Rap-Ciliman Software (Rapfish modification). Rap-Ciliman stands for Rapid Appraisal for Ciliman. The MDS-Rapfish approach was first developed by Pitcher (1999) to assess the sustainability status of world fisheries. This approach is based on the Multi Criteria Analysis (MCA) principle by relying on an algorithm called the MDS algorithm (Fauzi and Anna 2005). Multidimensional Scaling (MDS) is a statistical analysis technique that carries out multidimensional transformation (Kavanagh and Pitcher, 2004).

This technique is considered quite reliable to know the sustainability status of a management including the management of raw water in the Ciliman watershed. The importance of modifying MDS-Rapfish, so that, the dimensions and attributes studied are specific related to raw water management in the Ciliman watershed. In addition, this method is chosen considering that it can provide more stable results. This is consistent with 
J. Eng. Applied Sci., 15 (2): 567-573, 2020

Pitcher and Preikshot and in Fauzi and Anna (2005) that the MDS approach in Rapfish provides stable results compared to other multivariate analysis methods (factor analysis). In the MDS method there are two points or the same object mapped in a point adjacent to each other. Conversely, objects or points that are not the same are depicted with far apart points. The ordination or distance determination technique in MDS is based on Euclidian distance in dimensionless space. The closeness between objects is obtained by the Euclid distance formula (Euclidean distance):

$$
\mathrm{d}_{\mathrm{ij}}=\sqrt{\sum_{\mathrm{k}=1}^{\mathrm{p}}\left(\mathrm{x}_{\mathrm{ik}}-\mathrm{x}_{\mathrm{jk}}\right)^{2}}
$$

Where:

$\mathrm{d}_{\mathrm{ij}}$ : Euclidean distance or distance between objects $\mathrm{i}$ and $\mathrm{j}$

$\mathrm{p}$ : Number of dimensions

$\mathrm{x}_{\mathrm{ik}}$ : Value of line $\mathrm{i}$ and the column $\mathrm{k}$

$\mathrm{x}_{\mathrm{jk}}$ : Value of line $\mathrm{j}$ and column $\mathrm{k}$

The technique used in regressing the above equation is the ALSCAL algorithm (Fauzi and Anna, 2005). The ALSCAL method optimizes the square distance (square) against the square data (origin $=\mathrm{O}_{\mathrm{ijk}}$ ) which in three dimensions ( $\mathrm{i}, \mathrm{j}, \mathrm{k}$ ) is written in a formula called S-Stress as follows:

$$
s=\sqrt{\frac{1}{m} \sum_{k-1}^{m}\left[\frac{\sum_{i} \sum_{j}\left(d_{i j k}^{2}-0^{2}{ }_{i j k}\right)^{2}}{\sum_{i} \sum_{j} 0^{4}{ }_{i j k}}\right]}
$$

where, the square distance is the Euclidian distance weighted or written:

$$
\mathrm{d}_{\mathrm{ijk}}^{2}=\sum_{\mathrm{a}-1}^{\mathrm{r}} \mathrm{w}_{\mathrm{ka}}\left(\mathrm{x}_{\mathrm{ia}}-\mathrm{x}_{\mathrm{ja}}\right)^{2}
$$

Goodness of fit in MDS is reflected in the magnitude of the S-Stress value which is calculated based on the above $S$ value and $R^{2}$. Low stress values indicate good fit while high $\mathrm{S}$ values indicate otherwise. In the Rapfish approach, a good model is indicated by a stress value smaller than 0.25 or $\mathrm{S}<0.25$ (Fauzi and Anna, 2005). A good $\mathrm{R}^{2}$ value is $\mathrm{R}^{2}$ whose value is close to 1 .

Through MDS, the position of the sustainability point can be visualized in two dimensions, the horizontal axis
Table 1: Index sustainability category

\begin{tabular}{ll}
\hline Value index & Category \\
\hline $0-25$ & Bad; not continuous \\
$26-50$ & Less; less sustainable \\
$51-75$ & Enough; quite sustainable \\
$76-100$ & Good; very sustainable \\
\hline
\end{tabular}

and the vertical axis. The horizontal axis shows the difference in the system studied in the "bad" $(0 \%)$ to "good" (100\%) ordinance for each dimension analyzed. Whereas the vertical axis shows the difference from the attribute score mix between the systems studied. The results of the analysis produce a value where this value is the sustainability index value of the system under review. This ordination analysis can also be done to analyze how far the sustainability status for each dimension is. An overview of the sustainability analysis between dimensions can be visualized in an elevated diagram (kite diagram).

The sustainability scale of the system under study has a interval of $0-100 \%$. If the index value is more than $50 \%$, then the system under study can be categorized as sustainable and if the index is $<50 \%$ then the system under study is categorized as not/not yet sustainable. In this study sustainability criteria are based on Pitcher (1999) as follows (Table 1):

Sensitivity analysis (leverage) in this study was conducted to see which attributes were very dominant or sensitive affecting sustainability compared to other attributes. To evaluate the impact of random errors on all dimensions in the ordinance value estimation process Monte Carlo analysis is used with the method of "scatter plot” (Kavanagh, 2001; Fauzi and Anna, 2005). This analysis is a simulation method that reveals possible aspects of uncertainty, among the others, the impact of scoring errors due to lack of information, the impact of diversity in scoring due to differences in assessment, errors in data entry and high stress values obtained from ALSCAL algorithm.

An assessment of the sustainability of raw water utilization is carried out with a management dimension approach which includes, environmental dimensions, economic dimensions, social dimensions, institutional and legal dimensions and the dimensions of technology and infrastructure. The five dimensions are expected to show the level/status of sustainability of raw water utilization, so that, various sustainable management steps can be formulated. Determination of dimensions, indicators and measurement indicators are based on research results, legislation, national standards and expert opinion (Table 2). 
Table 2: Attributes for evaluating the sustainability of raw water supply in the Ciliman watershed

\begin{tabular}{|c|c|c|}
\hline No. & Dimension & Attributes \\
\hline A & Environment/ecology & $\begin{array}{l}\text { Annual flow coefficient, turbidity level of water, erosion index, run off coefficient, frequency of } \\
\text { drought, frequency of flooding, availability of raw water, sediment load, rainfall, land usage, } \\
\text { suitability of land use and adequacy of land cover area }\end{array}$ \\
\hline B & Social & $\begin{array}{l}\text { Local wisdom on water management, community education level, conflict of water extraction, } \\
\text { community understanding of natural resource sustainability, population pressure, population growth rate } \\
\text { and community participation in watershed management }\end{array}$ \\
\hline $\mathrm{C}$ & Economic & $\begin{array}{l}\text { Number of connections, percentage of the number of lower class people, potential of tourism objects, } \\
\text { availability of raw water availability fund, level of utilization of water, investment climate, income } \\
\text { of farmers from agriculture, employment of farmers and the level of welfare of the population }\end{array}$ \\
\hline $\mathrm{D}$ & Institutional and legal & $\begin{array}{l}\text { Availability of raw water legislation and enforcement of rules, collaboration between stakeholders, } \\
\text { clarity of responsibilities for natural resource management, capacity of relevant local government } \\
\text { agency/agency organizations, coordination between institutions/agencies and availability of customary } \\
\text { law }\end{array}$ \\
\hline $\mathrm{E}$ & Technology and infrastructure & $\begin{array}{l}\text { Support for facilities and infrastructure supplying raw water, value of building water, level of } \\
\text { acceptance of technological innovation, condition of water supply installation, level of raw water service } \\
\text { and condition of distribution network }\end{array}$ \\
\hline
\end{tabular}

\section{RESULTS AND DISCUSSION}

Sustainability status of ecological dimensions: Environmental dimension sustainability is an indicator of the sustainability of raw water supply related to environmental aspects; physical, chemical and biological. Environmental aspects are one of the important aspects in watershed management (Fig. 1).

Using Rap-Ciliman analysis on the 12 attributes, the sustainability index value of the ecological dimension of 56.53 was found on that account it is quite sustainable (the index is located between the values of 51.00-75.00). The results of leverage analysis for environmental aspects obtained shows that there are 3 attributes that becomes levers of sustainability; the frequency of floods, frequency of drought and coefficient of run-off around the Ciliman watershed with an RMS value of approximately 3.77, 3.49 and $2.53 \%$, respectively. Kavanagh and Pitcher (2004) state that the RMS value indicates the magnitude of the role of each attribute towards sensitivity to sustainability status.

This means that to increase the value of sustainability in the ecological dimension there must be special policy interventions to deal with flood and drought problems and the magnitude of the run-off around the Ciliman watershed. Water and flood are like two sides of a coin. Without water there could be no flood. So, flooding is a follow-up factor from the presence of water. In hydrology, water is a cycle that continues to exist. In a wider scope, the flood can be seen as a part of the hydrological cycle that is in the part of the water on the surface of the Earth that moves into the sea. Handling the problems of flooding and drought around the Ciliman watershed as one of the keys to sustainable environmental management is very important in the supply of raw water in the Ciliman watershed. Floods that occur during the rainy season are due to among others, siltation in the estuary where surface erosion and landslides in the upper reaches of the watershed and the influence of sea tides cause

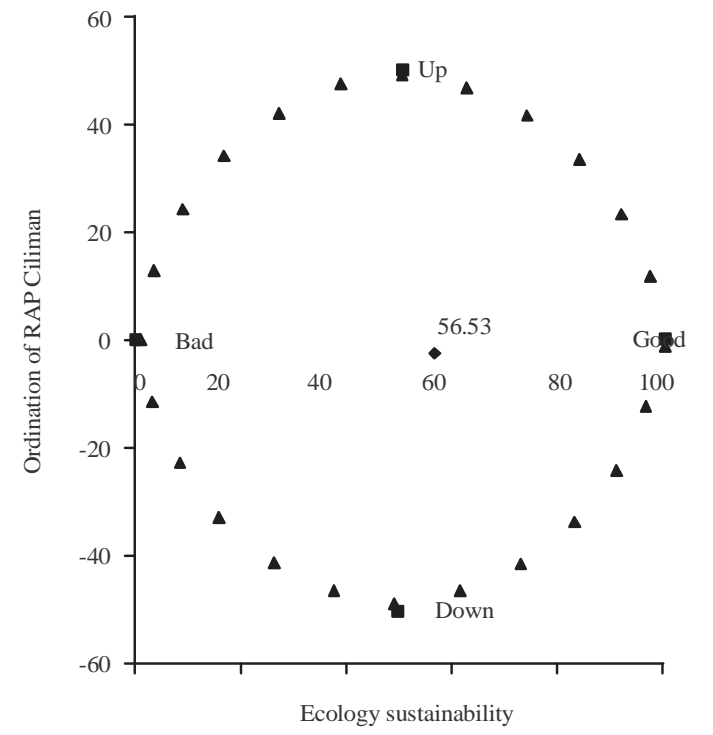

Fig. 1: Graph of ecological sustainability ordinances and leverage attributes

sedimentation and siltation at the mouth of the Ciliman river. So, it is necessary to intervene in the form of sedimentation control due to erosion and landslides in the upper watershed by making water catchment areas by making critical lands planted with trees, so as to reduce runoff, limit inappropriate land use changes, tighten mining permit $\mathrm{C}$ in the form of sand, dredging (normalization) river flow to reduce siltation, heighten river dikes to increase river capacity and so on.

Sustainability status of social dimensions: Sustainability status of social dimension is an indicator of the sustainability of raw water supply related to social aspects. The social aspect is one indicator of the sustainability of sustainable development (Fig. 2).

The results of the analysis shows that the sustainability index value for the social dimension of 


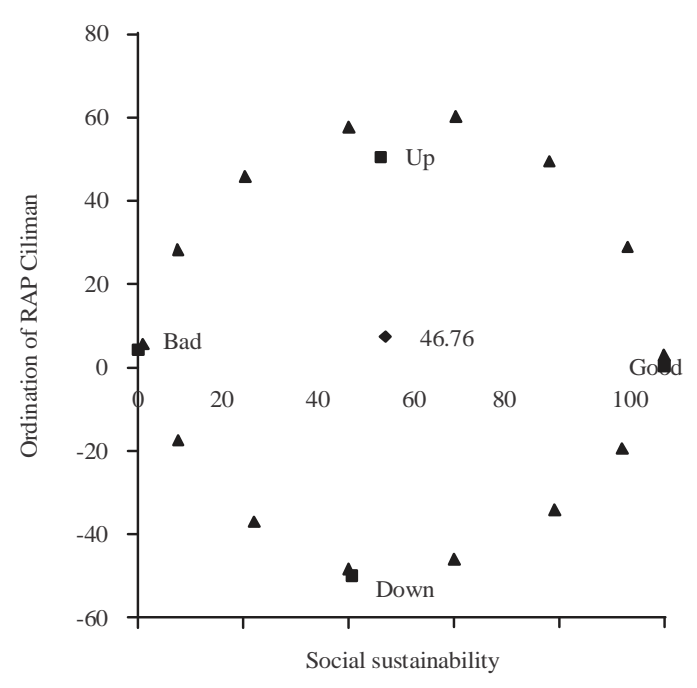

Fig. 2: Graph of social sustainability ordinances and leverage attributes

46.76 means that it is not sustainable (the index is located between the values of 26-50). There are several things that cause the value of the social dimension sustainability index to be not optimal. The results of the leverage factor analysis on 7 attributes in the social dimension based on the RMS value showed the 3 most sensitive attributes in the social dimension, namely the community's understanding of the sustainability of natural resources (4.82), population pressure (3.78) and community participation in watershed management $(2,10)$. Therefore, these three attributes must be considered in order to increase the value of socialdimensional sustainability. Possible interventions can be made to increase efforts towards the leveraging factors including efforts to disseminate information and provide counseling to the community, so that, the community understands the importance of preserving water and natural resources, involves the community in an effort to maintain and manage watersheds wisely and control population pressure on the watershed with the Land Availability Index (LAI) approach.

Sustainability status of economic dimensions: Economic sustainability is an indicator of the raw water sustainability supply related to economic aspects. Economic aspects become very important in the supply of raw water and watershed management and are one aspect of sustainable development (Fig. 3).

The results of the analysis using Rap-Ciliman on 9 attributes obtained the sustainability index value for the economic dimension of 62.90 means that it is quite sustainable (the index is located between the values of 51-75). Some attributes that are sensitive and affect this dimension are based on the results of leverage factor analysis on 9 attributes seen from the value

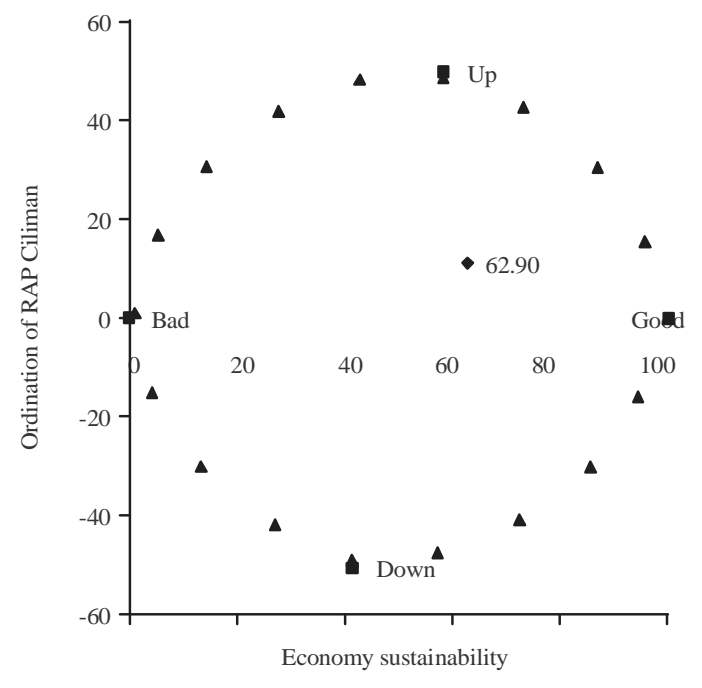

Fig. 3: Graph of economic sustainability ordinances and leverage attributes

of Root Mean Square (RMS), showing 3 very sensitive attributes, the availability of raw water supply funds (8.40), water utilization rates $(6,66)$ and the investment climate $(6,48)$. This shows that in order to improve sustainability in the economic dimension, the government must increase the funding of raw water supply through several investments in providing raw water sources with the use of appropriate technology, besides controlling the level of water utilization by the community by wisely socializing the use of sufficient water and improving the investment climate by preparing raw water facilities and infrastructure for various interests around the Ciliman watershed.

Sustainability status of institutional and law dimensions: Sustainability of institutional and legal indicates sustainability of raw water supply related to institutional, regulatory and regulatory aspects. Institutional and legal aspects are very important in the supply of raw water and overall watershed management (Fig. 4).

The results of the analysis using Rap-Ciliman on 6 attributes a sustainability index value for institutional and legal dimensions of 46.13 was obtained means less sustainable the index is located between the values of 26-50. There are several things that cause the value of the dimensional sustainability index institutions and laws are not maximal. The results of the leverage factor analysis on 6 attributes on the institutional and legal dimensions based on the RMS value show 2 of the most sensitive attributes in the institutional and legal dimensions, namely institutional organizational capacity (8.89) and clarity responsibility for natural resource management (8.56). 
J. Eng. Applied Sci., 15 (2): 567-573, 2020

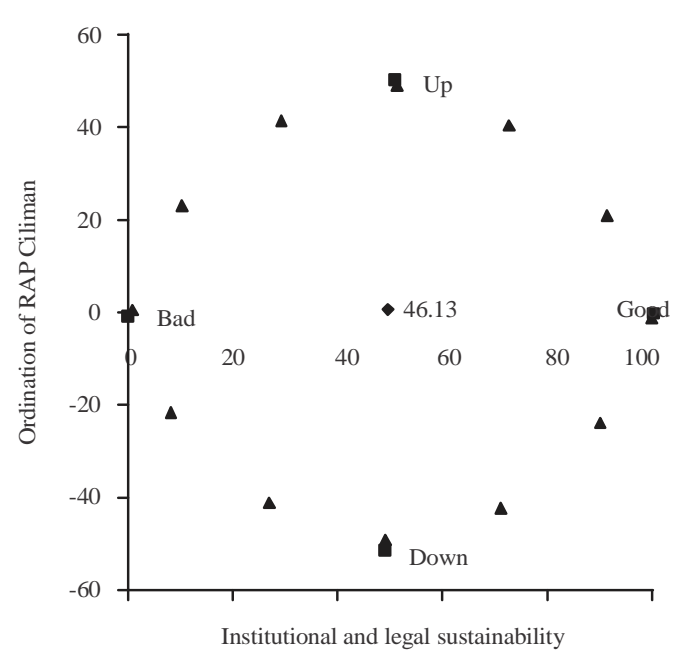

Fig. 4: Graph of institutional and law sustainability ordinances and leverage attributes

Administratively, the area of the Ciliman watershed in Lebak regency is $28,726.96$ ha $(57.13 \%)$ covering 3 sub-districts, namely: Cirinten, Gunung Kencana and Banjarsari. While the area of the Ciliman watershed located in Pandeglang regency is 21,555.57 ha (42.87\%) spreads across 7 sub-districts, namely: Angsana, Munjul, Panimbang, Patia, Sindangresmi, Sobang and Sukaresmi. The two regional governments have the same importance and priorities that are not necessarily the same as the existence of the Ciliman watershed from an economic, social and environmental perspective. To increase the sustainability index value in this dimension, coordination between the Regional Governments of Pandeglang, Lebak Regency and Banten Provincial Government are very important, especially in increasing the role of each institution/institution related to the use of the Ciliman watershed and the distribution of roles and responsibilities of natural resource management, especially the Ciliman watershed management.

Sustainability status of technology dimensions: The sustainability of the technology and infrastructure indicates the sustainability of raw water supply related to the aspects of technology and infrastructure (Fig. 5).

The results of Rap-Ciliman analysis of 6 attributes, obtained a sustainability index value for the dimensions of technology and infrastructure of 66.49 means that it is quite sustainable (the index is located between the values of 51.00-75.00). However, efforts are still needed to improve these aspects of technology and infrastructure. In order for the index of sustainability of the technology and infrastructure aspects to be improved, it is necessary to know what attributes are the most sensitive and become attributes of leveraging sustainability. This aims to

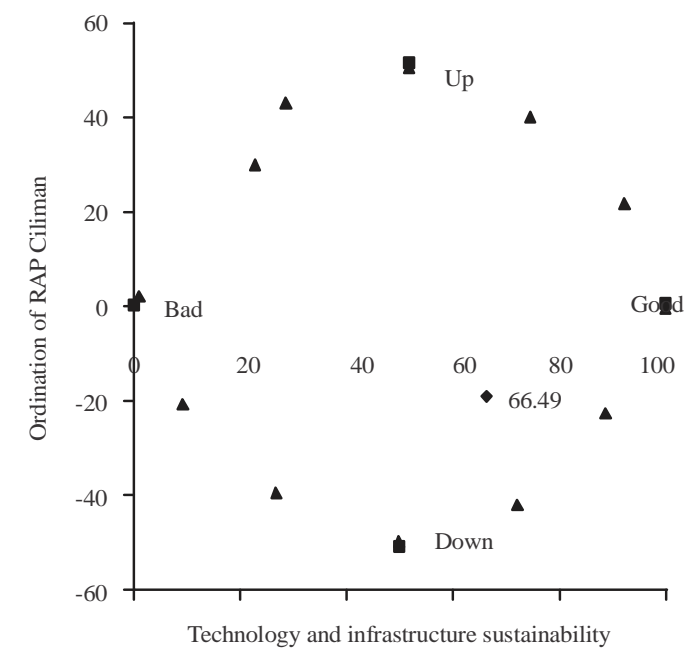

Fig. 5: Graph of technology sustainability ordinances and leverage attributes

determine the role of each attribute of the technology and infrastructure dimensions expressed in the form of changes in RMS.

\section{CONCLUSION}

The results of the study of the sustainability status of raw water supply in the Ciliman watershed, found that the level of sustainability of management in general is categorized as sufficiently sustainable including; ecological dimension $56.53 \%$ (quite sustainable), $62.90 \%$ economic dimension (quite sustainable), $46.76 \%$ social dimension (less sustainable), institutional and legal dimensions $46.13 \%$ (less sustainable) and technological dimensions and infrastructure $66.49 \%$ (quite sustainable). The main lever attributes of sustainability include; ecological dimensions namely; flood frequency (3.77), drought frequency (3.49) and run off coefficient (2.53), economic dimension; availability of raw water supply funds (8.40), water utilization rates (6.66) and investment climate (6.48), social dimensions; public understanding of the sustainability of natural resources (4.82), population pressure (3.78) and community participation in watershed management (2.10), institutional and legal dimensions; organizational capacity of the institution (8.89) and clarity of responsibilities for natural resource management (8.56), dimensions of technology and infrastructure; Water building value (9.49), acceptance level for technological innovation (8.61) and type of water supply installation (8.06).

\section{ACKNOWLEDGEMENTS}

Special thanks to Postgraduate Program of Environmental and Resources Management, Bogor Agricultural University. 


\section{REFERENCES}

Arikunto, S., 2006. [A Research Procedures Practice Approachb]. Penerbit PT. Rineka Cipta, East Jakarta, Indonesia, (In Indonesian).

Fauzi, A. and S. Anna, 2005. [Modeling Fisheries and Marine Resources for Policy Analysis]. PT Gramedia Pustaka Utama, Central Jakarta, Indonesia, ISBN:9789792212334, Pages: 343 (In Indonesian).

Hora, S.C., 2004. Probability judgments for continuous quantities: Linear combinations and calibration. Manage. Sci., 50: 597-604.

Kavanagh, P. and T.J. Pitcher, 2004. Implementing microsoft excel software for rapfish: A technique for the rapid appraisal of fisheries status. BA Thesis, Fisheries Centre Research Reports, University of British Columbia, Vancouver, Canada.

Kavanagh, P., 2001. Rapid appraisal of fisheries (RAPFISH) project. Rapfish Software Description (for Microsoft Excel), University of British Columbia, Fisheries Centre, Vancouver, Canada, pp: 36.
Munasinghe, M., 1993. Environmental Economics and Sustainable Development. The World Bank, Washington, D.C., USA., ISBN:9780821323526, Pages: 112.

Nasution, S., 2011. Research Method. PT. Bumi Aksara, East Jakarta, Indonesia,.

Pitcher, T.J., 1999. Rapfish, a rapid appraisal technique for fisheries and its application to the code of conduct for responsible fisheries. FAO Fish. Circ., Vol. 1,

Sugiyono, 2010. Statistics for Research. Alfabeta. CV., Bandung, Indonesia,.

Todaro P.M. and S.C. Smith, 2003. Economic Development in the Third World. Erlangga Group, Jakarta, Indonesia,.

World Commission on Environment and Development, 1987. Our Common Future. Oxford University Press, Oxford, UK., ISBN-13: 978-0192820808, Pages: 400.

Yusuf and Daris, 2018. Data Analysis of Research, Theory and Applications in the Field of Fisheries. IPB Press, Bogor, Indonesia,.

Yusuf, M., 2016. Tallo river estuary environmental management model makassar urban area. Master Thesis, International Peace Bureau, Berlin, Germany. 